Original Article

\title{
OPTIMIZATION OF ROLL COMPACTOR VARIABLES AND FORMULATION OF ANTI- RETROVIRAL TABLET BY ROLL COMPACTION METHOD
}

\author{
SUHAS H. LAHANE* \\ Department of Pharmaceutics, MET's Institute of Pharmacy, Pune University, Nasik 422003 \\ Email: suhaschandralahane@gmail.com
}

Received: 09 Oct 2019, Revised and Accepted: 03 Dec 2019

\begin{abstract}
Objective: This study emphasis on roll compaction variable and how the processing parameters influence the formation of granules in process of formulations of antiretroviral IR Tablet with help of optimization technique.

Methods: In this present work we aimed to develop a stable pharmaceutical dosage form with anti-retroviral drug tenofovir disoproxil fumarate. \% retention of granules over \# 60 mesh in roll compaction method by sizing with 50G co-mill screen was assessed by optimization and results were evaluated by Design expert 12.0 software. Various parameters and optimization of the parameter for formulation for better product was done by using $2^{3}$ factorial design and dry granulation technique for manufacturing tablets. Three operating parameters the roller speed, the hydraulic pressure and the gap width on the Chamunda CPMRC-200/150 Roll Compactor were varied. The planned response variable for study was \% retention over \#60 ASTM mesh. \% retention of granules was calculated by weighing granules on digital electronic balance with respect to how much premix material was taken for compaction.
\end{abstract}

Results: Excipients compatibility study gave positive way showing no change in physical appearance of drug-excipients mix. It reviled that drug was compatible with excipients used.

By formation of granules with required ratio, the value of Compressibility index changed from 29 to 21.89, showed that flow properties were improved i.e. from poor to passable.

Design expert 12.0 gave optimized solution for formation of required quantity of granules. Pareto chart showed envaulted positive and negative impact of factors on response as explained in results.

The results clearly indicate that how granules manufacturing in roll compaction process are influenced by roller pressure, roller gap and speed. 70 $\%$ flakes formation and granules retention were observed with $4000 \mathrm{~kg} / \mathrm{cm}^{2}$ pressure, $1 \mathrm{~mm}$ roller gap width and $6 \mathrm{rpm}$ speed of roller.

Pareto chart clearly indicate major impact is of roller pressure. Comparative dissolution profile graph showed that drug release pattern is similar with the innovator tablet.

A stable, robust tablets were formed at the end of process.

Conclusion: In this study, by optimizing processing variables stable antiretroviral immediate release oral solid dosage form was formed.

Keywords: Dry granulation, Roll compactor, Optimization, Antiretroviral, Tenofovir disproxil fumarate (TDF), Immediate release tablet

(C) 2020 The Authors. Published by Innovare Academic Sciences Pvt Ltd. This is an open access article under the CC BY license (http://creativecommons.org/licenses/by/4.0/] DOI: http://dx.doi.org/10.22159/ijpps.2020v12i1.36016. Journal homepage: https://innovareacademics.in/journals/index.php/ijpps

\section{INTRODUCTION}

An awesome fact is that since time immemorial i.e. over the past decades oral ingestion has long been the most convenient and commonly employed route of drug delivery. Oral route is the most preferred route of drug administration due to its non-invasive nature, administration convenience, and highest patient compliance with low production cost and design flexibility. Despite tremendous advancements in drug delivery, the oral route retains the ability of being the preferred route for the administration of therapeutic agents [1-3]. A granulation process step is often mandatory when Active pharmaceutical ingredients or formulation excipients have very poor flow property. The flowability of powders has major impact in successful formulation of tablets. If the powder is with poor flowability, it will lead to segregation of the blend and resultantly non-uniform distribution of blend from hopper to feeder (force/gravity) and leading to non-uniform die-fill volume and content non-uniformity of the prepared tablets [4]. Tenofovir disproxil fumarate (TDF) belongs to class of anti-retroviral drugs knows as nucleotide analogue reverse transcriptase inhibitors (NtRTIs) which blocks reverse transcriptase an enzyme crucial to viral production in HIV-infected people. Chemically, TDF is 9[(R)-2-[[bis [[(isopropoxycarbonyl) oxy] methoxy] phosphinyl] methoxy] propyl] adenine fumarate $[5,6]$. The unit dose of the drug is $300 \mathrm{mg}$. The drug is white to off white amorphous powder, is fine, fluffy in nature and exhibits poor flowability.
Poor flow of powder results in bridging in hopper, arching, rat holing, no flow [7]. Granulation, excipient combination has effect on flow ability. Hence here granulation method chosen as dry granulation by roller compaction method. Roll Compaction/Dry Granulation (RCDG) is a granulation method in which is densification/compaction of powder(s) is done by passing it between two counter-rotating rollers [8]. The RCDG technique has significant effect on fluidity, compressibility and compactibility influencing drug release profile and tablet properties. The word optimize means perfect, effective or functional as possible. The term optimization is often used in pharmacy relative to formulation and processing. In general terms, the optimum solution is those value of the factors which, when taken together, give the best values for two or more dependent variables. Optimal factor values depends on the process objective i.e. to maximize process yield or reduce product variability [9]. As given in ICH guidelines for quality by design (Qbd), Quality cannot be tested into the product that is quality should be built in by design [10] Three operating parameters the roller speed, the hydraulic pressure and the Auger speed on the Chamunda CPMRC-200/150 Roll Compactor were varied. The planned response variable for study was $\%$ retention over \#60 ASTM mesh. Factorial designs are the design of choice for simultaneous determination of the effects of several factors and their interactions. Roll compaction/dry granulation (RCDG) is a technique of choice for dealing out/processing of physically or chemically moisture sensitive drugs, as no liquid binder is essential in the granulation. This 
literature review exemplifies the advancement and the use of RCDG in the production of directly compressible excipients, the compaction of drugs and drug formulations.

The aim of study was to optimize various parameter that affect manufacturing of flakes and ultimately reteained granules so the final effect will be on stable dosage form [11].

\section{MATERIALS AND METHODS}

Tenofovir Disproxil Fumarate (Hetero Lab), Lactose monohydrate (Signet Chemicals pvt ltd.), Microcrystalline cellulose Avicel PH 102(FMC Biopolymer), Sodium starch glycolate (Sigma chemicals India), Croscarmellose Sodium (Colorcon pvt ltd.), Magnesium stearate (Nitika pharma). The compaction was done on Chamunda GMP roll compactor Model-CPMRC 200/150. Screening of flakes into granules was done by using Qudro co-mill (M/s Gansons Ltd. India)
In this study, three aspect of the control of roller compactor were adjusted to evaluate the effect on the resultant granulate namely roller speed, compaction force and roller gap as discussed.

\section{Physicochemical characterization of drug}

Bulk density and tapped density of the API (100 gm) was determined as per method-1 (USP $30-\mathrm{NF} 25$, measurement in a graduated cylinder) using powder density tester (Electrolab). The compressibility index and hausner ratio were studied to determine flow property [12]. The drug excipient compatibility was done on 40 ${ }^{\circ} \mathrm{C} / 75 \% \mathrm{RH}$, the accelerated storage condition [13] [ICH Q1A (R2)] for a period of $4 \mathrm{w}$.

Formulation of dosage form under optimization of process variables of compaction process

Tablets were formulated by using composition as shown in table 1 .

Table 1: Composition of tablet

\begin{tabular}{lll}
\hline S. No. & Ingredients for tablet & $\mathbf{\%}$ \\
\hline & Compaction Part & 43.47 \\
1. & Tenofovir Disproxil Fumarate (TDF) & 20.86 \\
2. & Lactose Monohydrate & 14.28 \\
3. & Microcrystalline Cellulose PH 102 & 0.14 \\
4. & Magnesium stearate & 14.28 \\
5. & Lubrication Part & 2.86 \\
6. & Microcrystalline Cellulose PH 102 & 2.29 \\
7. & Croscarmellose Sodium & 1 \\
8. & Sodium Starch Glycolate & 100 \\
& Magnesium stearate & $3 \%$ Weight gain \\
\hline
\end{tabular}

TDF, Lactose monohydrate were co-sifted through 30\# sieve. Then microcrystalline cellulose was sifted through $40 \#$ sieve. All sifted material was mixed in double cone blender for $10 \mathrm{~min}$. Magnesium stearate sifted through 60\# sieve, then added in blender and mixed for 5 min. This premix material was used for compaction. After compaction flakes or ribbon produced were sized by using quadro co-mill. Screen used was 050 grated $(1.20 \mathrm{~mm})$. After that this sized material was sifted by using $60 \#$ sieve. $60 \#$ retained granules were collected in polybag and 60\# passed fines in another polybag.

If desired weight of granules is achieved then granules and fines were mixed in double cone blender for $5 \mathrm{~min}$. Blended with extra granular sifted excipients for $10 \mathrm{~min}$. Finally lubricated with Magnesium stearate sifted through $60 \#$ sieve for $3 \mathrm{~min}$. This blend was compressed by using 16.5 X $8.5 \mathrm{~mm}$ punch on Karnavati compression machine to form tablets.

\section{Roll compaction}

A roll compactor generally consists of three major units: a feeding system, which conveys the powder to the compaction area between the rolls; a compaction unit, where powder is compacted between two counter rotating rolls to a ribbon by applying a force; and a size reduction unit, for milling the ribbons to the desired particle size. Several operational parameters can be adjusted/controlled to modify the product granulate; the compaction force, the gap width and the milling size, roller rpm, auger rpm being the main variables. For this study, the variation in the compaction force and the gap width, roller rpm was investigated with respect to the quality and quantity of the granulate [14].

\section{Design of experiments/factorial design for granulation process}

Factorial design is an efficient method of indicating the relative significance of number of variable and their interaction. In present study, Hydraulic pressure/compaction force, roller speed, roller gap width effects were considered. These three variables were considered at two level i.e. lower and upper level hence it was a $2^{3}$ factorial design. The factors and range for roller compaction parameters were as shown in table 2.

Table 2: Critical process parameter for factorial design

\begin{tabular}{llll}
\hline Factor & Name & Unit & Low level \\
\hline Factor 1 & Roller speed & Rpm & 3 \\
Factor 2 & Hydraulic pressure/Compaction force & $\mathrm{kg} / \mathrm{cm} 2$ & 2000 \\
Factor 3 & Roller gap width & $\mathrm{Mm}$ & 1 level \\
\hline
\end{tabular}

According to factorial design and considering these three variables, eight experiments had been performed. The response was \% of granules over 60\# ASTM sieve. Each experiment involved three cycles for compaction to achieve desired ratio of granules to fines. Finally, after eight batches, optimized process parameters were taken for compaction and final batch compacted and evaluated for flow properties. This optimized batch granules were taken for formulation of tablet. Finally, tablets were coated for $3 \%$ weight gain per tablet. Tablets were compressed at parameters as shown in table 3.

The tablets of optimized batch were evaluated for weight variation, Assay, disintegration test, In vitro-dissolution test [15]. In vitro-drug release study was carried out using USP (Apparatus 2-paddle method) dissolution apparatus at $37+0.5 \mathrm{oC}$ with constant stirring rate of $50 \mathrm{rpm} / \mathrm{min}$. The formulated tablets were tested for drug 
release in $0.1 \mathrm{~N} \mathrm{HCl}$ for $45 \mathrm{~min}$. A sample volume of $10 \mathrm{ml}$ was withdrawn from each dissolution vessel at regular intervals and replaced with equal volume of fresh dissolution medium. The withdrawn samples were filtered through $0.45 \mu \mathrm{m}$ nylon filter. The amount of drug released was determined by spectrometer at 259 nm. Six tablets were taken from each batch for dissolution study and average value at each time point was taken for drug release study. Film coating of tablets was done by using auto coater to maintain the physical and chemical of tablets. The parameter for coating is as shown in table 4.

Table 3: Compression parameter for tablet

\begin{tabular}{lll}
\hline S. No. & Parameter & Limit \\
\hline 1. & Appearance & White to off white capsule shape tablet plain on both side \\
2. & Weight & $690 \mathrm{mg}+5 \%$ \\
3. & Thickness & $5.80+0.2 \mathrm{~mm}$ \\
4. & Hardness & NLT $50 \mathrm{~N}$ \\
5. & Disintegration Test & NMT $15 \mathrm{~min}$. \\
6. & Friability Test & NMT $1 \%$ \\
\hline
\end{tabular}

Table 4: Coating parameter for tablets

\begin{tabular}{lll}
\hline S. No. & Parameter & Limit \\
\hline 1. & Pan RPM & $12-16 \mathrm{rpm}$ \\
2. & Inlet air Temperature & $50-70 \mathrm{oC}$ \\
3. & Exhaust air Temperature & $40-60 \mathrm{oC}$ \\
4. & Bed Temperature & $40-45 \mathrm{oC}$ \\
5. & Atomizing air pressure & $2-4 \mathrm{~kg} / \mathrm{cm}^{2}$ \\
6. & Spray pump RPM & $5-15 \mathrm{rpm}$ \\
7. & Spray rate & $5-10 \mathrm{ml} / \mathrm{min}$ \\
8. & Spray gun Nozzle diameter & $1.5 \mathrm{~mm}$ \\
\hline
\end{tabular}

\section{RESULTS AND DISCUSSION}

Physicochemical characterization of drug was done. The results of flow property test indicated poor flow of drug. Hence to improve flowability and compressibility dry granulation was done. The results were as shown in table 5 .

The results of drug-excipient physical compatibility studies revealed that drug was compatible with the excipients studied, as no physical change in the appearance of the drug-excipients mix was observed as shown in table 6.

Therefore it was concluded that the drug can be formulated by combining drug with mentioned excipients.

\section{Optimization of roller compactor variables}

The optimization with regard to one or more attributes has always been a subject of importance and attention. The word "optimize" means perfect, effective or functional as possible. The term "optimization" is often used in pharmacy relative to formulation and processing. In general terms, the optimum solution is those values of the factors which, when taken together, give the "best" values for two or more dependent variables. Optimal factor values depend on the process objective i.e. to maximize process yield or reduce product variability $[16,17]$.

Certainly, human input is an essential ingredient of the creative process. In addition to the art of formulation, techniques are available that can support the scientist's choice of formulation components which will optimize one or more product attributes $[18,19]$.

Design of experiments run details and observation are tabulated in table 7. It was concluded that slow speed for roller provides more compaction as it gives sufficient time to form cohesion/bridge between particles. Hence slow roller speed provides more agglomeration of material. Hydraulic pressure/compaction force has direct relation with compaction.

Table 5: Physicochemical characterization of drug

\begin{tabular}{llll}
\hline S. No. & Test & Specification & Results \\
\hline 1. & Description & White to off white powder & White to off white powder \\
2. & Solubility & Sparingly Soluble in Ethanol and Methanol & Complies \\
3. & Moisture content & NMT $1 \%$ & $0.76 \%$ \\
4. & Bulk Density & -- & $0.460 \mathrm{gm} / \mathrm{ml}$ \\
& Tapped Density & -- & $0.644 \mathrm{gm} / \mathrm{ml}$ \\
& Hausner's ratio & -- & 1.4 \\
5. & Compressibility Index & $114-118{ }^{\circ} \mathrm{C}$ & 29 \\
6. & Melting Point & NLT $97 \%$ and NMT $101 \% \mathrm{w} / \mathrm{w}$ & $114.5^{\circ} \mathrm{C}$ \\
\end{tabular}

Table 6: Drug excipients compatibility study

\begin{tabular}{|c|c|c|c|c|c|c|c|}
\hline \multirow[t]{2}{*}{ S. No. } & \multirow[t]{2}{*}{ Combination } & \multirow[t]{2}{*}{ Ratio } & \multirow[t]{2}{*}{ Physical appearance } & \multicolumn{4}{|c|}{ Observation at $40{ }^{\circ} \mathrm{C} / 75 \% \mathrm{RH}$} \\
\hline & & & & $1 \mathrm{~W}$ & $2 \mathrm{~W}$ & $3 \mathrm{~W}$ & $4 \mathrm{~W}$ \\
\hline 1. & API & -- & Off white & $\mathrm{NC}$ & NC & NC & $\mathrm{NC}$ \\
\hline 2. & API-Lactose Mono. & $1: 10$ & Off white & $\mathrm{NC}$ & NC & NC & NC \\
\hline 3. & API-Microcrystalline cellulose PH102 & $1: 10$ & Off white & $\mathrm{NC}$ & NC & NC & NC \\
\hline 4. & API-Croscarmellose Sodium & $1: 2$ & Off white & NC & NC & NC & NC \\
\hline 5. & API-Sodium Starch Glycolate & $1: 2$ & Off white & NC & NC & NC & NC \\
\hline 6. & API-Magnesium Stearate & $1: 0.5$ & Off white & NC & NC & NC & NC \\
\hline
\end{tabular}

Description: NC-No change 
Table 7: Design of experiment run and observation

\begin{tabular}{|c|c|c|c|c|c|}
\hline Batch code & $\begin{array}{l}\text { Factor } 1 \\
\text { roller speed (RPM) }\end{array}$ & $\begin{array}{l}\text { Factor } 2 \\
\text { compaction force }\left(\mathrm{kg} / \mathrm{cm}^{2}\right)\end{array}$ & $\begin{array}{l}\text { Factor } 3 \\
\text { roller gap width }(\mathrm{mm})\end{array}$ & $\begin{array}{l}\text { Cycles } \\
\text { (No.) }\end{array}$ & $\begin{array}{l}\text { Response \% retention } \\
\text { over } 60 \# \text { sieve }\end{array}$ \\
\hline FB1 & 3 & 2000 & 1 & 3 & $57 \%$ \\
\hline FB2 & 9 & 2000 & 1 & 3 & $56 \%$ \\
\hline FB3 & 3 & 4000 & 1 & 3 & $72 \%$ \\
\hline FB4 & 9 & 4000 & 1 & 3 & $67 \%$ \\
\hline FB5 & 3 & 2000 & 2 & 3 & $58 \%$ \\
\hline FB6 & 9 & 2000 & 2 & 3 & $55 \%$ \\
\hline FB7 & 3 & 4000 & 2 & 3 & $62 \%$ \\
\hline FB8 & 9 & 4000 & 2 & 3 & $61 \%$ \\
\hline OB1 & 6 & 4000 & 1 & 3 & $70 \%$ \\
\hline
\end{tabular}

Description: FB-Factorial Batch, OB-Optimized Batch

A high compaction force gave more compacted flakes and resulted into more granules. Harder granules obtained when high pressure was given while low compaction force provide soft granules in less quantity. Less roller gap results into more densification/compaction of material. A combined effect of slow roller speed, high hydraulic pressure and less roller gap results into high densification/ compaction. Three compaction cycles taken in present study. Eight factorial design batches taken and evaluated toward highest productivity of granules. \% retention of granules over $60 \#$ sieve varied between 55 to $72 \%$ in these eight different trials. As compared to roller speed and gap width, more impact is of compaction force. By using Design of experiment calculation excel sheet optimum parameters value for roller speed, compaction force, roller gap width decided to get higher desired response value i.e. \% retention over 60 \# sieve. Compaction force was kept to higher side i.e. $4000 \mathrm{~kg} / \mathrm{cm}^{2}$, Roller gap kept to lower side i.e. $1 \mathrm{~mm}$. Roller speed was kept at $6 \mathrm{rpm}$ by giving emphasis on both on quality as well as output i.e. production of granules. Finally, by using this optimum solution for factor, compaction was done in optimized batch OB 1 . Resultant granules that retained over 60 \# sieve was $70 \%$. Rest of manufacturing process was done as described previously to formulate tablet.

\section{Pareto chart}

Pareto chart is a useful tool for showing others the relative size of effects. These are useful to separate the "vital few" from the "trivial many" issues. Pareto charts are useful in gaining a deeper understanding of root cause or discovering possible "high-leverage" points to begin to impact change.

Here Hydraulic pressure/compaction force factor has a major effect on the particle size. It indicates the Hydraulic pressure/compaction force factor have most significant effect in formation of flakes. Factor below t-limit has non-significant effect. Qualitatively it can observe from Pareto chart that the range in which turret speed was used have least effect. Roller gap width has more effect than Roller speed.

Hydraulic pressure/compaction force showing positive effect. It can be considered to have highest effect for formation of flake. While roller speed has least effect.

Pareto chart was as shown in fig. 1.

\section{Characterization/evaluation of tablet}

Bulk density of granules was found to be $0.449 \mathrm{gm} / \mathrm{ml}$ while tapped density was found to be $0.568 \mathrm{gm} / \mathrm{ml}$. Compressibility index and hausner's ratio were calculated from these values i.e. 21.89 and 1.27 respectively. These micrometrics properties show passable flow property and compressibility. Physical characteristics or post compression parameters of tablets were evaluated. Results were satisfactory and as shown in table 8 .

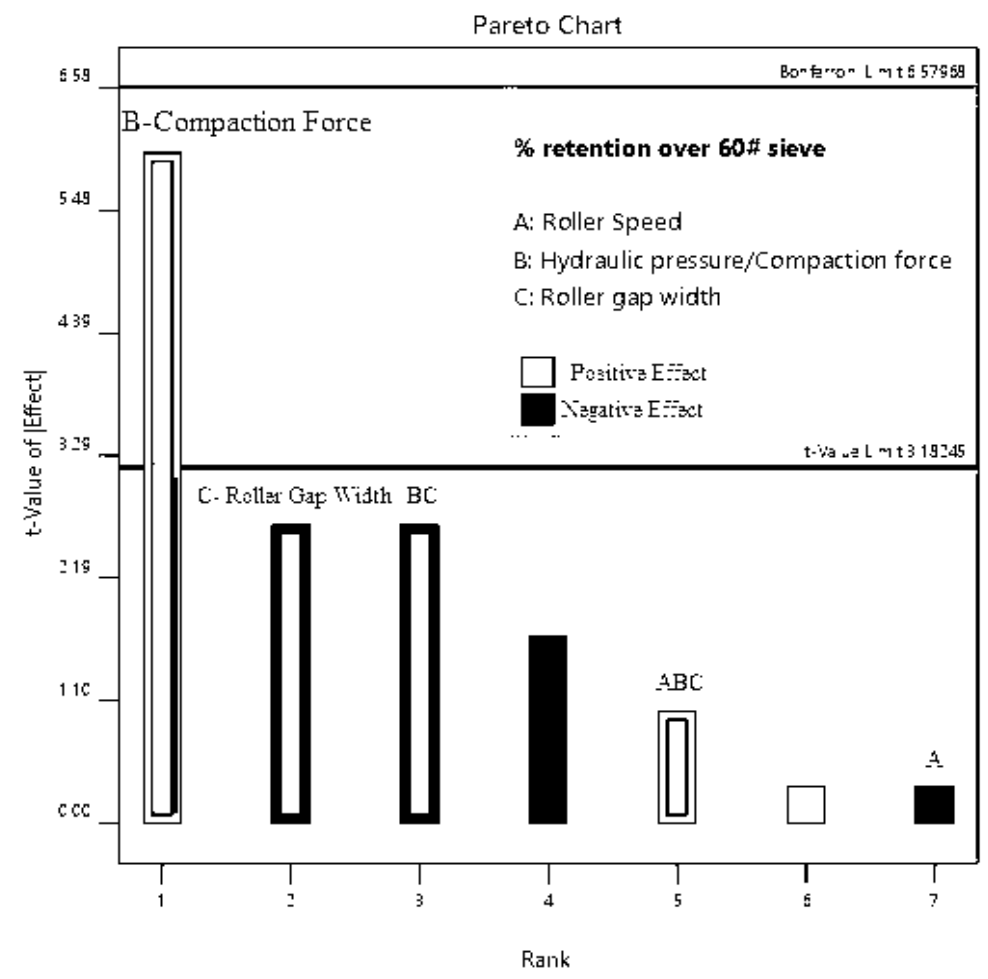

Fig. 1: Pareto chart created by design expert v.12.0 related to the given data 
Table 8: Characterization of tablets

\begin{tabular}{llll}
\hline S. No. & Property & Core tablets & Coated tablets \\
\hline 1. & Appearance & White colored, biconvex, capsule shaped & Orange colored, biconvex, capsule shaped \\
2. & Average Weight & $688-700 \mathrm{mg}$ & $708-715 \mathrm{mg}$ \\
3. & Thickness & $5.75-5.84 \mathrm{~mm}$ & $5.90-5.96 \mathrm{~mm}$ \\
4. & Hardness & $50-90 \mathrm{~N}$ & $120-140 \mathrm{~N}$ \\
5. & Friability & $0.09 \%$ & -- \\
6. & Disintegration Time & $1 \mathrm{~min} 45 \mathrm{sec}$ & $2 \mathrm{~min}$ to $2 \mathrm{~min} 10 \mathrm{sec}$ \\
\hline
\end{tabular}

Assay of tablets was found to be 99.0 to $101.3 \%$. The drug release from tablets was ranged from 96.5 to $100.1 \%$. Detailed results about dissolution study was as shown in table 9. Dissolution profile of formulated tablet was compared with innovator (Viread) Tablets and shown in fig. 2.

Table 9: Dissolution profile at different point of formulation

\begin{tabular}{lll}
\hline Time (min) & \% Drug release from formulated tablets & \% Drug release from Innovator (Viread) \\
\hline 0 & 0 & 0 \\
5 & 40.2 & 37.2 \\
10 & 61.9 & 56.1 \\
15 & 79.5 & 73.5 \\
30 & 97.8 & 97.2 \\
45 & 100.3 & 99.3 \\
\hline
\end{tabular}

Note-Results of dissolution are average value.

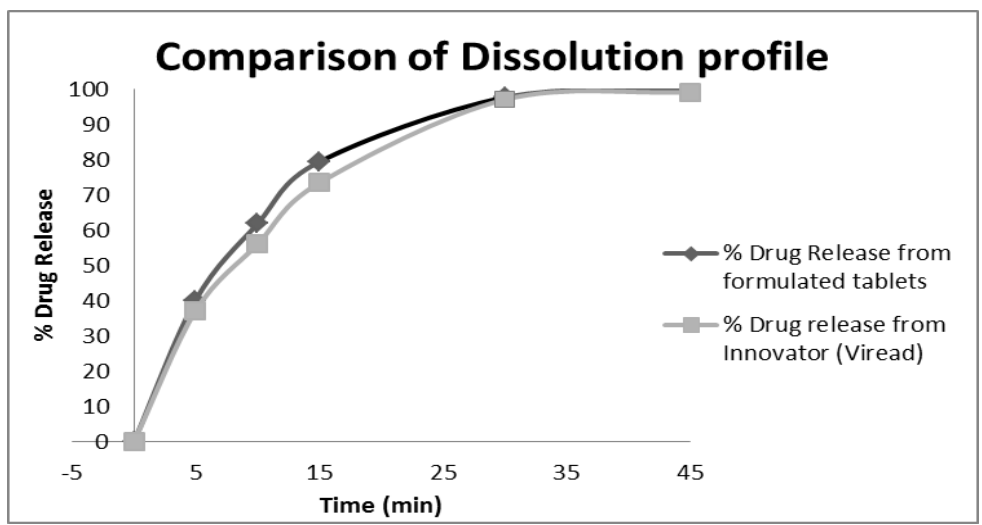

Fig. 2: Comparison of dissolution profile of innovator with test

\section{CONCLUSION}

The use of dry granulation, that is, Roller Compaction, has increased recently in the development and manufacturing of pharmaceutical dosage forms. In present study, a successful attempt has been made to formulate an antiretroviral molecule into immediate release tablet by dry granulation/roller compaction method. Critical variable having impact on compaction process has been identified and controlled to produce desired target response. Pareto chart is a useful tool for showing others the relative size of effects. It gives deeper understanding that root cause in formation of flakes and retained granules is majorly compaction force after that distance between rollers is major factor. $2^{3}$ factorial design, Design expert software, Pareto chart are the new technique to find out important factor that impact quality.

With respect to Quality by Design requirements, these results demonstrate that it is possible to control Critical Process Parameters in order to achieve required retained granules $\%$ and granules properties.

\section{ACKNOWLEDGEMENT}

Extremely gratified to Formulation Development Department and research lab for helping in technical aspect of project.

\section{FUNDING}

Nil

\section{AUTHORS CONTRIBUTIONS}

Individually worked in this piece of work.

\section{CONFLICT OF INTERESTS}

The author declared no conflict of interest.

\section{REFERENCES}

1. Poddar S, Shajahan A. A review on a flexible technology for modified release of drugs: multi layered tablets. J Controlled Release 2004;97:393-405.

2. Vijayalaxmi S, Umasri N. Formulation development and in vitro evaluation of tenofovir disproxil fumarate (TDF) immediate release tablets. Indo Am J Pharma Sci 2017;4:1229-41.

3. Kaur G, Sridhar D, Gera M. Optimization of roll compaction/Dry granulation (Rcdg) process for poorly flowable antiviral formulation. Am J Pharmtech Res 2012;2:2249-3387.

4. Sinka IC, Motazedian F, Cocks ACF, Pitt KG. The effect of processing parameters on pharmaceutical tablet properties. Powder Technol 2009;189:276-84.

5. Kannan K, Manikandan M, Selvamuthukumar S, Manavalan R. Formulation development and evaluation of emtricitabine and tenofovir disproxil fumarate tablets. Int J Drug Dev Res 2012;4:247-56.

6. Durghe N, Parida K, Roy H. Formulation development and characterization of antiretroviral agents. Int J Pharma Res Health Sci 2016;4:1517-26.

7. Baxter T, Bamum R, Prescott J. Flow: general principles of bulk solid handling. In: Augsburger L, Hoag S. editor. Pharmaceutical Dosage form: Tablets, Newyork, Informa healthcare; 2008. p. 77, 87, 128.

8. Yu S, Gururajan B, Reynolds G, Roberts R, Adams MJ, Wu CY. A comparative study of roll compaction of free-flowing and 
cohesive pharmaceutical powders. Int $\mathrm{J}$ Pharm 2012;428:39-47.

9. Armstrong N. Pharmaceutical experimental design and interpretation. 2nd Ed. Newyork, Taylor and fransis group; 2006. p. 83, 135.

10. Notari R. Biopharmaceutics and clinical pharmacokinetics, an introduction. 4th Ed. Newyork, Marcel Dekker; 1987. p. 176-8.

11. Bolton S, Bon C. Pharmaceutical's statistics: practical and clinical applications. 4th Ed. USA, Informa Healthcare Inc; 2004. p. 222-7.

12. United States Pharmacopoeia/National Formulary. 24th ed. Rockville MD: Pharmacopeial Convection; 2006. p. 242.

13. ICH, Q1A(R2), Stability Testing of New Drug Substances and Products, in: Proceedings of the International Conference on Harmonisation, Geneva; 2003.

14. Freeman T, Bey H, Hanish M, Brockbank K, Armstrong B. The influence of roller compaction variables on the rheological properties of granules. Asian J Pharma Sci 2016;11:516-27.
15. Banker G, Anderson N. Tablets. In: Lachman L, Lieberman H, Kanig J. editor. The theory and practice of industrial pharmacy. 3rd Ed. New Delhi, CBS publishers and distributors; 2009. p. 171-96, 293-345.

16. Podczeck F. Theoretical and experimental investigation into the delamination tendencies of bilayer tablets. Int J Pharm 2011;408:102-12.

17. Lachman L, Lieberman HA, Joseph LK. The theory and practice of industrial pharmacy. 4nd ed. India: Varghese Publishing house: 1991. p. 293-303, 311-317, 317-335, 442-443.

18. Lieberman HA, Lachman L, Schwartz JB. Pharmaceutical and dosage form: Tablet. 2th ed. Marcel Dekker, Inc; 1989. p. 188190, 414, 564.

19. Bolton $S$, Bon C. Pharmaceutical statistics: practical and clinical applications. 4th ed. USA: Informa healthcare Inc; 2004-15. p. 16, 222-7, 265, 269. 